BJHS 53(2): 255-278, June 2020. C The Author(s) 2020. This is an Open Access article, distributed under the terms of the Creative Commons Attribution licence (http://creativecommons. org/licenses/by/4.0/), which permits unrestricted re-use, distribution, and reproduction in any medium, provided the original work is properly cited.

doi:10.1017/S0007087420000059 First published online 08 April 2020

\title{
Programming the USSR: Leonid V. Kantorovich in context
}

\author{
IVAN BOLDYREV" AND TILL DÜPPE**
}

\begin{abstract}
In the wake of Stalin's death, many Soviet scientists saw the opportunity to promote their methods as tools for the engineering of economic prosperity in the socialist state. The mathematician Leonid Kantorovich (1912-1986) was a key activist in academic politics that led to the increasing acceptance of what emerged as a new scientific persona in the Soviet Union. Rather than thinking of his work in terms of success or failure, we propose to see his career as exemplifying a distinct form of scholarship, as a partisan technocrat, characteristic of the Soviet system of knowledge production. Confronting the class of orthodox economists, many factors were at work, including Kantorovich's cautious character and his allies in the Academy of Sciences. Drawing on archival and oral sources, we demonstrate how Kantorovich, throughout his career, negotiated the relations between mathematics and economics, reinterpreted political and ideological frames, and reshaped the balance of power in the Soviet academic landscape.
\end{abstract}

\section{In the service of plenty}

One of the driving forces of Western science in the twentieth century was the notion of promoting rationality in modern societies. However, many believed that scientific rationality might be best nurtured in the socialist context of a planned economy. That was the hope of the progressive Soviet intelligentsia that had its peak during the post-Stalinist decades of the 1960s and 1970s. During the same decades as in the United States,

* Radboud University Nijmegen, Institute for Management Research, Postbus 91086500 HK, Nijmegen, Netherlands. Email: i.boldyrev@fm.ru.nl.

* Department of Economics, Université du Québec à Montréal, Pavillon des Sciences de la gestion, 315, Rue Sainte-Catherine Est, Montréal (Québec), H2X 3X2, Canada. Email: duppe.till@uqam.ca.

We are grateful for comments and help we received from Olav Bjerkholt, Erwin Dekker, Anton Dmitriev, Paul Erickson, Slava Gerovitch, Karl Hall, János M. Kovács, Mark Levin, Vyacheslav Nekrasov and Perry Mehrling. We are also grateful to Alexander Bukhvalov, Viktor Danilov-Danilyan, Askold Khovansky, Veniamin Livshits, Valery Makarov, Valerii Plisko, Joseph Romanovsky, Anatoly Vershik and Vladimir Zhiyanov for sharing their memories with us. We also appreciate the research assistance of Ruslan Mamedov and Irina Kraineva. This research has been funded by the Insight Development Grant of the Canadian Social Sciences and Humanities Research Council, SSRHC (file number 430-2017-00439), as well as by the Bundesministerium für Bildung und Forschung 'Modernisierungsblockaden in Wirtschaft und Wissenschaft der DDR'. Ethics approval has been granted by the Comité institutionnel d'éthique de la recherche avec des êtres humains (CIEREH, UQAM, S-703440). 
economic knowledge in the USSR became increasingly technical. ${ }^{1}$ Fuelled by the vision of achieving prosperity through science, this project had to confront, and adjust to, different ideological premises.

Consider the following twofold image of knowledge in socialism: on the one hand, freed from bourgeois ideology, it had to be fundamentally different from that in capitalism. This was the traditional requirement of Marxist political economy. ${ }^{2}$ On the other hand, in moving from the Great Patriotic War to the Cold War, knowledge was also a 'productive force' in the competition of the two systems for the same goal of prosperity and should thus be symmetric in both systems. In the following, we describe the negotiations of these two images of knowledge amplified by various identity conflicts between disciplinary cultures, party loyalty and social reformism. We show how, through these negotiations, a new scientific persona emerged that was characteristic of Soviet socialism after Stalin. The transformation of economic knowledge at the height of the Soviet Union parallels the construction and performance of a distinct Soviet scientific persona as a partisan technocrat. The career of Leonid Kantorovich (1912-1986) stands for the intricacies of how this scientific persona became established. ${ }^{3}$

Kantorovich was one of the main protagonists of Soviet science in the wake of Stalin. $\mathrm{He}$ is particularly known as the pioneer of linear programming, which he imagined to apply not only on the level of a production unit, but on a national level - thus 'programming the USSR'. This brought him in conflict with the establishment of Marxist political

1 Soviet economic knowledge has been subject to major studies such as Slava Gerovitch, From Newspeak to Cyberspeak: A History of Soviet Cybernetics, Cambridge, MA: MIT Press, 2002; Till Düppe and Ivan Boldyrev (eds.), Economic Knowledge in Socialism, 1945-1989, Durham, NC: Duke University Press, 2019; Ivan Boldyrev and Olessia Kirtchik, 'General equilibrium theory behind the Iron Curtain: the case of Victor Polterovich', History of Political Economy (2014) 46(3), pp. 435-461; Boldyrev and Kirtchik, 'The cultures of "mathematical economics" in the postwar Soviet Union: more than a method, less than a discipline', Studies in History and Philosophy of Science, Part A (2017) 63, pp. 1-10; Till Düppe, 'Koopmans in the Soviet Union: a travel report of the summer of 1965', Journal of the History of Economic Thought (2016) 38(1), pp. 81-104; Adam Leeds, 'Dreams in cybernetic fugue: Cold War technoscience, the intelligentsia, and the birth of Soviet mathematical economics', Historical Studies in the Natural Sciences (2016) 46(5), pp. 633-668.

2 On the history of Marxist political economy of socialism in the Soviet Union see Ethan Pollock, Stalin and the Soviet Science Wars, Princeton, NJ: Princeton University Press, 2006; Till Düppe and Sarah Joly-Simard, 'Stalin's pluralism: how anti-dogmatism serves tyranny', Research in the History of Economic Thought and Methodology (2020) 38(B), pp. 37-54; Oleg Ananyin and Denis Melnik, 'Commodity sui generis: the discourses of Soviet political economy of Socialism', in Düppe and Boldyrev, op. cit. (1), pp. 75-99.

3 In this, we build on the work of Slava Gerovitch and his account of the technocratic nature of the postStalinist scientist. Slava Gerovitch, 'Stalin's rocket designers' leap into space: the technical intelligentsia faces the thaw', in Michael Gordin, Karl Hall and Alexei Kojevnikov (eds.), Intelligentsia Science: The Russian Century, 1860-1960, Osiris (2008) 23, pp. 189-209. See also Benjamin Peters, who wrote of 'cybernetic entrepreneurs', notably Viktor Glushkov and Anatoly Kitov, whose attempts at reshaping planning practices intersected with those of the partisan technocracy in the Academy of Sciences, to which Kantorovich belonged. Benjamin Peters, How Not to Network a Nation: The Uneasy History of the Soviet Internet, Cambridge, MA: MIT Press, 2016. For the notion of the persona in the history of science more generally see the pioneering work by Steven Shapin and Charles Thorpe, 'Who was J. Robert Oppenheimer? Charisma and complex organization', Social Studies of Science (2000) 30(4), pp. 545-590. On the historiography of life writing in science see, for example, Janet Browne, 'Making Darwin: biography and changing representations of Charles Darwin', Journal of Interdisciplinary History (2010) 40, pp. 347-373. 
economists in charge of national institutions. His career reveals how Soviet scientists could forge utopian visions of socialism by remoulding Marxist ideology and disciplinary structures, as well as engaging the rigid institutions of Soviet bureaucracy and the political class.

The existing accounts of Kantorovich's career are stories of a Great Man. ${ }^{4}$ They emphasize his struggle for scientific reason and increased efficiency in planning against the blind dogmatism of Marxist prejudice. So far, there is no contextual reconstruction of his career that shows the interplay of political conditions, disciplinary boundaries and authorial intentions. In this sense, our study adds to several recent accounts of Soviet academic careers that emphasize the contradictory and complex identities of the Soviet scientist. ${ }^{5}$ Oral interviews, new archival evidence, and closer readings of the published documents and interviews allowed us to approach Kantorovich's career in a more contextual way that embraces the full complexity of his persona. ${ }^{6}$ Kantorovich was indeed more Soviet than rebel, less vision-driven and more bureaucratic, defiant and more dependent regarding existing institutions, less anti-Marxist and more cautious of the transnational discourse; that is, he was more technocrat than intellectual, and more partisan than cosmopolitan.

In the first section, we show how the early transformation of science during Stalin enabled Kantorovich, socialized and trained as a mathematician, to pose economic questions, without, however, having any impact on Stalin's economist caste (1930-1953).

4 See, for example, Valery Makarov, 'Kantorovich, Leonid Vitalievich (1912-1986)', in Steven N. Durlauf and Lawrence E. Blume (eds.), The New Palgrave Dictionary of Economics, 2nd edn, Basingstoke: Palgrave Macmillan, 2008, pp. 7226-7228; Roy Gardner, 'L.V. Kantorovich: the price implications of optimal planning', Journal of Economic Literature (1990) 28(2), pp. 638-648; Natalya Iljina-Kantorovich and Jonathan V. Rosenhead, 'Silver medal', in Lev J. Leifman (ed.), Functional Analysis, Optimization, and Mathematical Economics: A Collection of Papers Dedicated to the Memory of Leonid Vital'evich Kantorovich, Oxford: Oxford University Press, 1990, pp. 46-48; Saul I. Gass and Jonathan Rosenhead, 'Leonid Vital'evich Kantorovich', in Arjang A. Assad and Saul I. Gass (eds.), Profiles in Operations Research, Vienna: Springer, 2011, pp. 157-170; Alexander V. Bukhvalov, 'Kantorovich and mathematical modeling in economics: synthesis of reality, mathematics and economics', Russian Management Journal (2012) 10(3), pp. 3-30.

5 In this, we follow the example of other studies that describe the scientists in the context of transnational relations, ideological allegiance and the military. Michael Gordin's A Well-Ordered Thing: Dmitrii Mendeleev and the Shadow of the Periodic Table, Princeton, NJ: Princeton University Press, 2018, an account of the life of Mendeleev, is an example for how to use life writing as a means to understand Russian science culture. See also Ksenia Tatarchenko, 'Calculating a showcase: Mikhail Lavrentiev, the politics of expertise, and the international life of the Siberian science-city', Historical Studies in the Natural Sciences (2016) 46(5), pp. 592-632, who reflected on the relation between life trajectory, geographical relocations and scientific virtues in her study of the mathematical physicist Mikhail Lavrentiev. See also the biography of Ivan Pavlov by Daniel P. Todes, Ivan Pavlov: A Russian Life in Science, Oxford: Oxford University Press, 2014.

6 Conversations were carried out with Alexander Bukhvalov, Viktor Danilov-Danilyan, Askold Khovansky, Veniamin Livshits, Valery Makarov, Joseph Romanovsky, Alexander Bukhvalov, Anatoly Vershik and Vladimir Zhiyanov. These informal witnesses show a high degree of personal loyalty, but also largely accord on Kantorovich's lack of political engagement, his conformism, shyness and uneasiness speaking in public-information that cannot be drawn from the archival sources that we consulted to reconstruct his career path (the State Archive of the Russian Federation, the Archive of the Russian Academy of Sciences, the Richard Stone Papers at King's College, Cambridge University, and the Koopmans Papers at Yale University). 
Having gained status thanks to his military work, we show in the second section how he managed, during Khrushchev, to mobilize Academy of Sciences allies, mitigated the critique by orthodox Marxists, and built up a new generation of technocratic scholars ready to transform economic planning (1954-1964). Finally, we describe the negotiations about this new form of Soviet scholarship through the struggles of granting scientific credit to Kantorovich: first, the Lenin Prize in 1965, and then, more astonishingly, the Nobel Prize for economics in 1975. We conclude with a discussion of the characteristic tensions between the partisan technocractic ideal and its fate in the Soviet state.

\section{Growing into Soviet mathematics during Stalin (1930-1953)}

In June 1930, at the age of eighteen and having already graduated in mathematics from Leningrad University, Kantorovich attended the First All-Union Congress of mathematicians in Kharkov. As before the revolution, mathematics was highly regarded, and a means for Russia to contribute to, and compete with, Western Europe. Russian virtuosi mathematicians, such as Aleksandr Lyapunov, Andrey Markov Sr and Vladimir Steklov, had made lasting contributions to the international mathematics community. The congress thus attracted the international mathematical elite of the day, and Kantorovich had been introduced to scholars such as Wilhelm Blaschke, Jacques Hadamard, Maurice Fréchet and Arnaud Denjoy.

The opening speech of the congress was, however, dominated by another tone. The algebraist Otto Schmidt, at that time one of the highest officials of Soviet science, declared the need for mathematics to contribute to building up socialism. In this, he thought of Stalin's politics of advanced industrialization, and the increasing demand for mathematical training of engineers. Not everyone agreed. Dmitri Egorov and Nikolai Günter, an old and respected mathematician in Leningrad and head of the Leningrad Physics and Mathematics Society, refused to send an official 'greeting' from the congress to the XVI Party Congress that was being held at the same time, and were criticized for trying to separate pure mathematics from dialectical materialism. Young Kantorovich signed a collective letter denouncing Günter, which remained the only time Kantorovich participated in collective campaigns. ${ }^{7}$

This conference symbolized Kantorovich's socialization into a world of conflicting mathematical practices that transformed the early Soviet institutions of mathematics and its patronage relations during Stalin - a transformation between cooperation, competition and isolation of the Soviet and the Western mathematical spheres. ${ }^{8}$ It was this

7 Egorov died in September 1931 during a hunger strike after being arrested, and Günter had to give up his chair and the presidency of the society that ceased to exist, though he remained professor at Leningrad University. See Leonid A. Leifert, Benzion I. Segal and L.I. Fedorov (eds.), Na leningradskom matematicheskom fronte, Moscow and Leningrad: Gos. sotsialno-econom. Izd, 1931; Nataliya S. Ermolaeva, 'O tak nazyvayemom "Leningradskom matematicheskom fronte"', Trudy SanktPeterburgskogo mat. Obshchestva (1998) 5, pp. 380-395. On Egorov see Loren Graham and Jean-Michel Kantor, Naming Infinity: A True Story of Religious Mysticism and Mathematical Creativity, Cambridge, MA: Harvard University Press, 2009.

8 This section, apart from interviews and other literature, draws from an account Kantorovich himself provided of his early socialization at the Moscow Mathematical Society that he was no more able to give 
transformation, as we will see in this section, which made the young mathematician Kantorovich address problems outside his own field.

Kantorovich was dedicated to mathematical training from a very early age. At age fourteen, he enrolled at Leningrad State University with special permission. There he was trained by Grigorii Fichtenholz, a leading mathematician in functional analysis. ${ }^{9}$ During his career, Kantorovich emphasized the continuity of his training in functional analysis and his work in applied mathematics. His older study colleagues, such as Ludvig Faddeev, Isidor Natanson, Solomon Mikhlin and, notably, Sergei Sobolev, remained part of Kantorovich's academic family. A second group working on functional analysis at Moscow State University was run by Abraham Plessner, the teacher of the two mathematicians whom Kantorovich would measure up, support and receive support from during his career: Andrey Kolmogorov and Israel Gelfand. ${ }^{10}$

Kantorovich had only two minor encounters with the applied field of economics before his graduation. In 1929, in his third year at university, he attended a lecture in political economy given by Aleksandr Voznesenkii, whose brother would become the head of the state planning committee, Gosplan. There he encountered another discursive world, the state-building doctrine, Marxism, seemingly removed from his own career track towards the Academy of Sciences. He also got acquainted with the workings of the 'real' economy when he took an obligatory internship in Tashkent, working with the Water Board in the summer of 1929. But there, all he could do was to count averages for statistics with pencil and paper.

Engineers being in high demand, on receiving his doctorate in 1930, and barely older than his students, Kantorovich received seven different teaching offers for engineers and became a professor of mathematics at Leningrad University, as well as, in 1932, at the Leningrad Higher School of Engineering in Industrial Construction and at the Higher School of Industrial Transport. He was encouraged by Aleksey Krylov, an applied mathematician, to embark on the field of approximation theory. Considered to be the opposite of pure mathematics, approximation theory was used in calculations for the planning of large-scale industrial projects. Kantorovich developed a method to transform a twodimensional minimization problem into one that was one-dimensional - a method that

himself. Leonid V. Kantorovich, 'My journey in science', Russian Math. Surveys (1987) 42(2), pp. $233-270$. We contextualize the episodes he chose to emphasize, and also those he chose to play down.

9 Kantorovich's first two publications, as well as many that would follow, were in French. See Leonid V. Kantorovich, 'Sur les suites des fonctions rentrant dans la classification de M.W.H. Young', Fundamenta Mathematicae (1929) 13, pp. 178-185; Kantorovich, 'Sur les ensembles, projectifs de la deuxième classe', Comptes rendus de l'Académie des sciences Paris (1929) 189, pp. 1233-1235.

10 See Slava Gerovitch, 'Creative discomfort: the culture of the Gelfand seminar at Moscow University', in Brendan Larvor (ed.), Mathematical Cultures: The London Meetings 2012-2014, Basel: Birkhäuser, pp. 51-70. The important role of Kolmogorov in Kantorovich's career has not yet been fully acknowledged in the literature. The correspondence between Kolmogorov and Kantorovich starting in 1930 shows that they considered themselves colleagues in a common cause: working on different aspects of functional analysis in various fields of application. In particular after Stalin, Kolmogorov was a key Soviet academician, fully endorsed by the party authorities, and the leader of the Soviet mathematical community. Though his work in linguistics is most known, his first, often unnoticed, scientific paper was in quantitative economic history. Andrey N. Kolmogorov, Novgorodskoe zemlevladeniye XV veka (Landownership in Novgorod in the Fifteenth Century), Moscow: Nauka, Fizmatlit, 1994. 
would be applied by the Construction Institute and the Central Aerodynamics and Hydrodynamics Institute. ${ }^{11}$

At the same time as Stalin's Great Purge of 1936-1938, but independently, Kantorovich witnessed a case of repression in mathematics, the so-called Luzin affair that once more reinforced the norm of nationalist mathematics. Nikolai Luzin, a student of Egorov, was publicly accused of being a counterrevolutionary, publishing pseudoscientific work, not sufficiently crediting his students, and sympathizing with monarchists. The charges were raised by Ernst Kolman, philosopher and Party watchdog, and supported by scholars (Sobolev and Schmidt) and Luzin's students (Kolmogorov included). A commission from the Academy of Sciences agreed, criticizing the fact that Luzin published abroad. This was sufficient bad press to close Luzin's department in the Steklov Institute, though harsher punishment was expected. ${ }^{12}$ Kantorovich did not partake in the campaign against Luzin. He might have kept a low profile since, as one of the Fichtenholz students, he could have been subject to the campaign too. Kantorovich's colleague Georg Lorentz claimed later that it was because of the necessity for teaching future engineers that 'the rantings of Kolman, Segal, Leifert, and others about dialectical materialism had no effect [and] Fichtenholz and his students Kantorovich, Natanson, and I, could continue to work in our selected fields'. ${ }^{13}$ Establishing his early career in this state of terror, Kantorovich, like many, stopped publishing abroad and withdrew from the international scene. ${ }^{14}$ In retrospect, he associates this withdrawal with the secrecy related to the starting battle against fascist Germany in which the entire country was included in 1939:

In 1936-1937 ... I felt some dissatisfaction with mathematics. Not because my work was uninteresting or unsuccessful, but because the world was facing a strange menacing brown plague-German fascism. It was clear that there was going to be a very hard war for some years that would threaten civilization. And I felt a responsibility, understanding that people out of the ordinary must do something ... I had a clear perception that the state of economic solutions was a weak spot that was reducing our industrial and economic power. ${ }^{15}$

11 See Leonid V. Kantorovich and Vladimir I. Krylov, Metody priblizhennogo resheniya uravnenii $v$ chastnykh proizvodnykh (Methods of Approximate Solution of Partial Differential Equations), Moscow and Leningrad: ONTI, 1936. Kantorovich's major theoretical contribution on the theory of vector lattices that is linked to his name (and still used in mathematical economics) dates from these days. See Leonid V. Kantorovich, 'Sur les propriétés des espaces semi-ordonnés linéaires', Comptes rendus de l'Académie des sciences Paris (1936) 202, pp. 813-816.

12 Luzin kept his title of academician and was not arrested. See Sergei Demidov and Boris Levshin (eds.), Delo akademika Nikolaya Nikolaevicha Luzina, Saint Petersburg: RKhGI, 1999; Christopher Hollings, 'The struggle against idealism: Soviet ideology and mathematics', Notices of the American Mathematical Society (2013) 60(11), pp. 1448-1458; Daniil A. Aleksandrov, 'Why Soviet scientists stopped publishing abroad', Voprosy Istorii Esteststvoznaniya i Tekhniki (1996) 3, pp. 4-24.

13 Georg G. Lorentz, 'Mathematics and politics in the Soviet Union from 1928 to 1953', Journal of Approximation Theory (2002) 116(2), pp. 169-223, 199.

14 In a letter to Kantorovich from 1934 Luzin praises his younger colleague as a future genius, promises to support his election to the Academy of Sciences and tries to secure his priority after learning that Kantorovich would write a section on analytic sets for the project of the Soviet Encyclopedia of Mathematics. Nikolai N. Luzin, 'A letter to L.V. Kantorovich', published by Yuri G. Reshetnyak and Semion S. Kutateladze, Vestnik RAN (1934/2002) 72(8), pp. 740-742.

15 Kantorovich, op. cit. (8), p. 253. 
This perception made him write a curious report entitled On the Allocation of Printed Products in 1937, which must have been one of the first proposals received by the Supreme Soviet of the USSR. The report addressed book shortages and inefficiencies in supplying different kinds of literature while suggesting measures that would satisfy the demand and eradicate existing shortages. ${ }^{16}$ This practical measure notwithstanding, the contribution that would later make him the founder of linear programming, and would profoundly transform the role of the mathematician in the Soviet Union (and the West), would be written and discussed on the eve of the Second World War. ${ }^{17}$

As the chair of the mathematics department at the Institute of Mathematics and Mechanics in Leningrad, Kantorovich was very visible to engineer colleagues. In 1938, engineers from the lab of the Plywood Trust asked him to solve a maximization problem regarding veneer-cutting machines of different productivities and different materials. The problem was described by a simple set of inequalities but Kantorovich's solution, reported to the Herzen Institute in October 1938, was general, using the duality principle. ${ }^{18}$ In January 1939, this became the algorithm to solve the linear-programming problem, published in a small booklet titled Mathematical Methods in the Organization and Planning of Production. ${ }^{19}$ This text was the first systematic application of linear optimization to economic problems and, as Eastern scholars would claim, the birthplace of linear programming as an autonomous mathematical discipline. ${ }^{20}$ It began the process that was to lead to his Nobel Memorial Prize in Economics, which was in turn closely intertwined with his role in developing the institutions of mathematical economics in the Soviet Union.

The booklet was distributed in the Soviet Union in an edition of one thousand copies only. Kantorovich did not wish to reach an international audience, as he considered his results strategically relevant:

At the beginning of 1940 I published a purely mathematical version of this work in Doklady Akad. Nauk, expressed in terms of functional analysis and algebra. However, I did not even put [in my booklet] a reference to my published pamphlet - taking into account the circumstances I did not want my practical work to be used outside the country. ${ }^{21}$

16 Vsevolod L. Kantorovich, Semion S. Kutateladze and Yakov I. Fet (eds.), Leonid V. Kantorovich: Chelovek $i$ uchenyii (Leonid V. Kantorovich: Man and Scientist), vol. 1. Novosibirsk: Scientific Publishing Center of RAS, 2002, pp. 237-249.

17 Among the many works treating mathematics during the Second World War and its impact on the postwar sphere see, for example, Amy Dahan-Dalmédico, 'An image conflict in mathematics after World War II', in Umberto Bottazzini and Amy Dahan-Dalmédico (eds.), Changing Images in Mathematics: From the French Revolution to the New Millennium, London: Routledge, 2001, pp. 223-253.

18 See Kantorovich, op. cit. (8), p. 254. The 1938 manuscript 'Some mathematical problems of the economics of industry, agriculture and transport' has been published in Russian. Leonid V. Kantorovich, Matematiko-ekonomicheskie raboty (Mathematical-Economic Articles), Novosibirsk: Nauka, 2011, pp. 626-632.

19 Leonid V. Kantorovich, Mathematicheskie Metody Organizatsii i Planirovania Proizvodstva, Leningrad: Leningrad State University Publishers, 1939, translated as 'Mathematical methods in the organization and planning of production', Management Science (1960) 6(4), pp. 366-422.

20 See, for example, Sonja Brentjes, 'Zur Herausbildung der linearen Optimierung', in Wolfgand Lassmann (ed.), Ökonomie und Optimierung, Berlin: Akademie, 1985, pp. 298-330.

21 See Kantorovich, op. cit. (8), p. 256. 


\section{2}

Ivan Boldyrev and Till Düppe

In his early years, mathematics was a means to increase the recognition of Russian science by Western European countries; now it was a secret means of competing with the same countries.

The booklet was timely: in March 1939, at the 18th Party Congress, economic efficiency became an official political concern, promising that the reorganization of labour would result in a GDP growth of 25 per cent. ${ }^{22}$ Kantorovich saw a similar potential in his work: if an optimization technique can be used in local planning at the firm level, why should it not be used at a national level as a basis for a 'socialist economics'? More than that, the mathematics of linear programming suggested that it could only be successful at the local level if global planning also followed the logic of optimization:

I began to understand the significance of these models for developing the principles of pricing, estimating effectiveness, at all events, the effectiveness of investments, that is, the basic features of the theory of linear economics for a socialist economy were created. ${ }^{23}$

As intuitive as the association of the local and national levels was, the audiences he needed to address would be very different. How would his technical approach to economic problems relate to the authoritative discourse of the political economy of socialism-Marx applied to a socialist economy-that was being simultaneously debated at the highest ranks, Stalin included? ${ }^{24}$ The discursive gap between the planning of local production and that of an entire nation would be the single most important obstacle in Kantorovich's career:

In the spring of 1939 I gave some more reports - at the Polytechnic Institute and the House of Scientists, but several times met with the objection that the work used mathematical methods, and in the West the mathematical school in economics was an anti-Marxist school, and mathematics in economics was a means for apologists of capitalism. ${ }^{25}$

And yet, Kantorovich must have been sufficiently encouraged, as in September 1942 he produced a more extensive and less mathematical exposition of his method. ${ }^{26} \mathrm{His}$ friend Sobolev sent this exposition to Gosplan, where it was considered by, among others, Grigorii Kosyachenko, Gosplan's deputy chairman. The submission must have been taken seriously, as Sobolev had won the Stalin Prize as early as 1941 and was a deputy of the Supreme Soviet of the Russian Republic (SFSR), which was still a significant position in the bureaucratic structure. In addition, such direct communication of ideas from civil to political institutions was encouraged, as it was a basic way to include, democratically, as it were, citizens in a planned centralized state. ${ }^{27}$ Nevertheless, how could the bureaucrats possibly assess the merits of a mathematical

22 Kantorovich, op. cit. (8), p. 252.

23 Kantorovich, op. cit. (8), pp. 256-257.

24 Pollock, op. cit. (2); Düppe and Joly-Simard, op. cit. (2).

25 Kantorovich, op. cit. (8), p. 256.

26 In the same year, he published a second, purely formal, paper to be published in English later. Leonid V. Kantorovich, 'O peremeshchenii mass' (Russian), Doklady Akademii Nauk SSSR (1942) 37(7-8), pp. 227-230 ('On the translocation of masses', Management Science (1958) 5, pp. 1-4).

27 See Till Düppe, 'The generation of the GDR: economists at the Humboldt University of Berlin caught between loyalty and relevance', History of the Human Sciences (2017) 30(3), pp. 50-85. 
algorithm as an actual protocol for running an efficient economy? Kantorovich needed to engage the attention and authority of the Academy of Sciences in order to mobilize the relevant bureaucratic interests.

There are not yet sufficient archival sources accessible that would enable the full reconstruction of the responses of Gosplan officials. They might not even have realized the challenge posed. As Kantorovich's colleague and son-in-law Joseph Romanovsky recalled in a personal conversation, they responded by saying, 'you do your job, we do ours'. Kantorovich himself recalled a fiercer reaction, as the very idea of changing current practices could have caused ideological accusation. According to Kantorovich, during the meeting at Gosplan, economist and statistician Boris Yastremskii said the following: " "You are talking here about optimum. But do you know who is talking about optimum? The fascist Pareto is talking about optimum." You know how that sounded in 1943.' ${ }^{28}$ In 1944, Kantorovich inquired again about his proposal, and received an official response from the head of Gosplan's Central Statistical Agency, Vladimir Starovsky:

Having examined your suggestions on the methodology of economic calculation and planning and having discussed them at a conference in which you participated, I consider any practical use of your suggestions in the work of the Gosplan of the USSR to be impossible. The Gosplan ... sent your work to the Academy of Sciences ... where a decision may be taken as to its theoretical value. ${ }^{29}$

Kantorovich took the signal seriously and turned away from national economic policy:

Everyone was saying that it was necessary to leave this work for the time being. It was dangerous to continue it - as I subsequently found out, my fear was not unfounded. Of course, this was a severe blow to me as I had put great faith in it. For some time I was even in a state of depression. ${ }^{30}$

What Kantorovich subsequently found out regarding the risks he took is difficult to assess. Terror might work through the very atmosphere of fear, but it was also clear that he was close to provoking the hostility of a Central Committee member. This was even more so as he was closely watched as a scientist involved in war research.

The 1941 German attack on the USSR had changed the conditions under which science was practised. Mathematicians, in particular, were in high demand. Kantorovich was involved in military applications of probability calculations and, after the war, in the atomic project, possibly as a result of his friend Sobolev's influence. Together with Ivan Petrovsky and Andrey Tikhonov (Moscow), Kantorovich played an important role in a group of mathematicians, arranged by the physicist Igor Kurchatov, who were calculating solutions to differential equations describing the explosion of the bomb. ${ }^{31}$ In the wake of the Second World War, as the nuclear arms race continued,

28 See Leifman, op. cit. (4), p. x; Kantorovich, Kutateladze and Fet, op. cit. (16), p. 59.

29 Kantorovich, Kutateladze and Fet, op. cit. (16), p. 374.

30 Kantorovich, op. cit. (8), p. 259.

31 See the complete documentation of the atomic project by Lev D. Ryabev (ed.), Atomnyi Proekt SSSR: Dokumenty I Materialy (USSR Atomic Project: Documents and Materials), 3 vols., Sarov and Moscow: RFNC-VNIIEF and Fizmatlit, 2010. Kantorovich is mentioned several times. In summer 1948, for example, he was freed from his teaching job to concentrate on calculations. His computer bureau in Leningrad was 


\section{4}

Ivan Boldyrev and Till Düppe

Kantorovich received one of the so-called Stalin Prizes, created to celebrate the scientists' share in the 'success' of the state. Formally, he received it for the totality of his work, with specific mention of the applications of functional analysis in calculation. ${ }^{32}$ Informally, it was clear that he received it for his work for the military and despite the unfavorable anti-Semitic campaigns of those days. ${ }^{33}$ This recognition was an important factor for the prominence he gained during the so-called Thaw. After Stalin's death, Kantorovich would become a symbol of a new form of partisan scholarship dedicated to a modern socialist state.

\section{Creating a partisan technocracy during the Thaw (1954-1964)}

Kantorovich renewed the attempts to see his ideas on mathematical economics implemented almost immediately after Stalin's death and even before the anti-Stalinist campaign. In July 1954, Sergei Vallander, vice rector of Leningrad University, sent a letter to Premier Georgy Malenkov, focusing on the importance of mathematics in economic policy, bemoaning the ignorance of mathematical methods among economists and planners, and actively promoting Kantorovich's work. ${ }^{34}$ It promised that Kantorovich's optimization methods would increase GDP by no less than 50-70 per cent and asked for a cross-disciplinary committee of economists, mathematicians and technical experts to evaluate his work. The letter was forwarded to Gosplan and the Central Statistical Administration (TsSU). Thus the highest authorities were involved.

Vallander received a response, copied to the Council of Ministers, from the Gosplan economists Gennady Sorokin and Vladimir Starovsky, the same individuals who rejected Kantorovich's approach in 1942. The arguments against Kantorovich's notion of optimal planning would become paradigmatic for many later critiques. First, there was ideological denial. Despite claims to the contrary, the optimal prices emerging from linear programming that Kantorovich cautiously labeled 'most expedient valuations' were seen as incompatible with the labour theory of value (labour does not appear to be the unique cause of value as other factors of production were considered in the same equation). Kantorovich's notion of investment efficiency based on profitability and cost minimization was criticized for its affinity with the bourgeois concept of the profit rate. ${ }^{35}$ When Kantorovich later renamed the parameters 'objectively determined valuations', the new contrivance was easily noticed as a way to avoid speaking about prices. Second, Gosplan economists considered the methods impractical, as too much

actively participating in the project until 1953. His co-author Lev Gor'kov recalled that Kantorovich was occasionally called upon by the military also in the 1960s. Interview by E. Gorokhova and M. Nastych in Vladimir Avtonomov et al. (eds.), Istoki, Moscow: HSE Publ., 2019.

32 Kantorovich, Kutateladze and Fet, op. cit. (16), pp. 153-160. Leonid V. Kantorovich, 'Funktsionalnyi analiz i prikladnaya matematika' (Functional analysis and applied mathematics), Uspekbi Mat. Nauk (1948) 3(6), pp. 89-185.

33 See Aron Katsenelinboigen, 'L.V. Kantorovich: the political dilemma in scientific creativity', Journal of Post Keynesian Economics (1978) 1(2), pp. 129-147.

34 GARF (State Archive of the Russian Federation), Vallander to Malenkov, letter, 09.07.1954, Coll. P-5446, Inventory 88, Document 1.

35 Kantorovich, Kutateladze and Fet, op. cit. (16), p. 445. 
information was required. They claimed, just as libertarian Friedrich von Hayek did in the West, that any calculation of optimal valuations would require enormous computational capacities, which they deemed impossible at that time. However, next to these two critical arguments, there was also partial acceptance. The application of Kantorovich's method of transport and rational cutting was considered acceptable, but at the level of the the provincial, local and industrial-as opposed to the national- planning authorities. $^{36}$

Rejected again by Gosplan, Kantorovich abandoned the political class in favour of targeting a different audience, the economic intelligentsia. He gave talks at various conferences and submitted his papers to Voprosy ekonomiki, the leading academic journal in Soviet economics, as well as to various public press journals, and found several allies. The immediate group, which would end up as the core of the community to be created, were the scholars from the older generation of economists open to mathematics. As early as 1940, Kantorovich was in touch with Viktor Novozhilov (1892-1970), a statistical economist from the Leningrad Polytechnic Institute who was internationally known for his work on business cycles before the war. ${ }^{37}$ Another well-known statistical economist and academician, Vasily Nemchinov (1894-1964), helped secure Kantorovich's reputation. Other older economists supported him, such as Aleksandr Konüs, Aleksandr Lur'e and Albert Vainshtein. However, only Nemchinov had any real influence in the Academy of Sciences.

Moreover, Kantorovich relied on the academic and political authority of his friends in mathematics and physics. In autumn 1956, Sobolev and the astrophysicist Victor Ambartsumian signed a letter, most likely written by Kantorovich himself, to the two highest officials of Soviet science: the chemist Alexander Nesmeyanov, chair and president of the Academy of Sciences, and the physicist Vladimir Kirillin, head of the Science and Education Department at the Party's Central Committee. ${ }^{38}$ The letter contained most of the arguments used by Kantorovich to defend his views. He stressed the lagging of the social sciences behind the natural sciences, gave cursory evidence of the real practical value of optimization techniques, stressed the relevance of linear programming in its natural connection to modern computing techniques, and noted the increasing popularity of these methods in the US, while arguing that they would prove more fruitful when applied in large-scale planning in a socialist economy. These clearly orchestrated moves do not suggest that Kantorovich confronted the system head-on, but knew how to approach Soviet bureaucracy and how to create his own space within it. The final recommendations in this letter were the following:

36 Leonid V. Kantorovich and Mark K. Gavurin, 'Primenenie matematicheskikh metodov v voprosakh analiza gruzopotokov' (The application of mathematical methods to freight flow analysis), in Vasily V. Zvonkov (ed.), Problemy Povysheniya Effectivnosti Raboty Transporta (Problems of Raising the Efficiency of Transport Performance), Moscow, Leningrad: Akademiia Nauk SSSR, 1949, pp. 110-138; Leonid V. Kantorovich and Viktor A. Zalgaller, Raschet Ratsionalnogo Raskroya Promyshlennykh Materialov (Calculation of Rational Cutting of Stock), Leningrad: Lenizdat, 1951.

37 Victor V. Novogilov, 'Essay', in William T. Foster and Waddill Catchings (eds.), Pollak Prize Essays: Criticisms of Profits, Newton, MA: Pollak Foundation for Economic Research, 1927.

38 Kantorovich, Kutateladze and Fet, op. cit. (16), p. 127. 
(1) The immediate publication of the works by Prof. L.V. Kantorovich and other authors, devoted to this set of issues. (2) Organizing the discussion of these methods in the frame of a competent meeting with the participation of academic economists, mathematicians, engineers, as well as practical men working in industry and planning organizations. (3) Organizing systematic research work devoted to the development of those methods in one of the existing or a special research institution. (4) Taking measures for making the wide range of economists, and, first of all, faculty and students of the engineering-economic schools, study these methods and organizing the relevant specialization at the mathematical departments of some universities. ${ }^{39}$

The subsequent history of Soviet mathematical economics can be seen as the implementation of that exact vision.

In implementing this vision, Kantorovich could also have called on the support of the international community of mathematical economists. Post-Stalin, his work was becoming known outside the USSR, but Kantorovich showed little interest in this. In November 1956, he received a letter from an economics-trained physicist from Chicago, Tjalling Koopmans, congratulating him on his contributions.

You have in part paralleled but in greater part anticipated a development of transportation theory in the United States which has stretched out over the period from 1941 to the present and is still continuing ... Your brief article contains in beautiful summary the mathematical essence of what was developed here. ${ }^{40}$

Kantorovich's response showed little excitement about Koopmans's work, nor was he interested in the priority issue raised in the letter. His response merely included a list of his own further contributions. Raymond P. Powell, possibly Kantorovich's first personal contact with Western economists, recalled meeting him in 1957:

I did succeed in seeing Kantorovich in Leningrad ... The interview was the oddest of my experiences in the Soviet Union ... The peculiar aspect of the exchange was that Kantorovich appeared almost paralyzed with nervousness. He barely spoke above a whisper. His hands trembled markedly. If sweat did not break out of his forehead, it looked as though it should. He insisted on speaking English, though his English was little better than my Russian ... He knew of 'some' practical applications of his ideas within single plants, though he spoke only of his fright-flow proposals. When I pressed him on the extent of such applications ... he shrugged his shoulders, Perhaps! Had the State Planning Commission shown any interest in his ideas? 'Well, they were in print; the people at Gosplan could read them if they wanted to.' The impression which he very clearly conveyed ... was that of a man who disclaimed all responsibility for, and interest in, his ideas, once they had left his pen ... I met this small-boy-in-the-cookie-jar attitude in talking with a few other Russians, though it was not common, least of all among urban intellectuals. ${ }^{41}$

39 Kantorovich, Kutateladze and Fet, op. cit. (16), p. 495 f.

40 In Tjalling Koopmans Papers, Box 13, Folder 'Kantorovich, Leonid V., 1956-59', Yale University. Koopmans was ahead of others noting Kantorovich's work. In Dantzig's account of the origins of linear programming Kantorovich is not mentioned (G.B. Dantzig (7 March 1957), 'Concepts, origins, and use of linear programming', P-980, the RAND Corporation); nor is he mentioned in the major economic book on the topic by Robert Dorfman, Paul Samuelson and Robert Solow, Linear Programming and Economic Analysis, New York: McGraw-Hill, 1958.

41 Powell to Koopmans, August 1957, Tjalling Koopmans Papers, op. cit. (40). 
This report certainly leaves open many interpretations, but it is clear that Kantorovich, as Koopmans might have wished, had no interest in cross-fertilizing with the Western Ivy League. $^{42}$

Instead, during the late 1950s, Kantorovich began to create his own audience of potential partisan scholars sharing his own scientific virtues. Until then, Soviet economic education contained only a few elements of mathematical training, no more than descriptive statistics. In 1958, Kantorovich proposed to establish the special division of 'economic-mathematical calculations' at Leningrad University. ${ }^{43}$ The rector of Leningrad University, the mathematician Aleksandr D. Aleksandrov, liked seeing his discipline spread over the campus and accepted the proposal. In the summer of 1959, the university decided to establish an additional year of mathematical training for selected economics undergraduates, the so-called ' 6 th course'. Students would then 'optimize' production processes at various sites in the Leningrad region or meet the increasing demand for university teachers of 'economic cybernetics'. Kantorovich thus could educate his own team of students who would form a new generation, with fast-tracked careers supported by the Party's calls for scientific-technical progress. ${ }^{44}$ Kantorovich compared himself with Valentina Gaganova, a forewoman at the cotton mill who became famous in 1958 by switching from a leading production team (that is, for Kantorovich, mathematics) to the one that was lagging behind (economics).

A parallel institutionalization of Kantorovich's methods in economics occurred in the Academy of Sciences and at Moscow University. In 1958, Nemchinov and Kantorovich organized a laboratory of economic-mathematical methods with one group in Moscow, headed by Nemchinov, and another in Leningrad, headed by Kantorovich. This group in Moscow would later become the core of the Central Economics and Mathematics Institute (CEMI), founded in 1963. ${ }^{45}$ In 1962, and following the lead of Leningrad, Nemchinov created a chair of 'mathematical methods of economic analysis' at Moscow State University that accepted students from 1960. In 1964, the division was

42 Kantorovich did read the Western literature. With Novozhilov, he overlooked a translation of a collection of papers on linear inequalities and related questions edited by Kuhn and Tucker in 1959. In 1959, Elena Ventsel managed to publish the first Soviet introduction in game theory. Elena Ventsel, Elementy Teorii Igr, Moscow: Fizmatgiz, 1959. Generally, many important works in mathematical economics in this period were quickly translated (such as Leontief, Karlin and Baumol). Kantorovich also met Harold Kuhn and Richard Bellman in Budapest in 1963, at the first international symposium on mathematical methods for economics organized by András Prékopa. András Prékopa (ed.), Colloquium on Applications of Mathematics to Economics, Budapest 1963, Budapest: Akadémiai Kiadó, Publishing House of the Hungarian Academy of Sciences, 1965.

43 See Alexander V. Bukhvalov and Anton L. Dmitriev, 'L.V. Kantorovich i shestoj kurs ekonomicheskogo fakulteta LGU v 1959 godu v rusle stanovlenija ekonomicheskoj nauki v Rossii’, in Edouard A. Tropp (ed.), Peterburgskaya academia nauk $v$ istorii akademij mira. K 275-letiu Akademii nauk. Materialy mezhdunarodnoj konferencii 28.06-04.07 1999, Saint Petersburg: SPb nauchnij tsentr RAN, 1999, pp. 208-224.

44 This generation of scholars is also discussed as the generation of the 1960s. See Joachim Zweynert, 'Shestidesyatniki economics, the idea of convergence, and perestroika', in Düppe and Boldyrev, op. cit. (1), pp. 277-299.

45 On CEMI see Leeds, op. cit. (1); and Richard Ericson, 'The growth and marcescence of the "System for Optimal Functioning of the Economy” (SOFE)', in Düppe and Boldyrev, op. cit. (1), pp. 155-179. 
renamed 'economic cybernetics', followed by other Soviet universities that established similar programmes.

Once cybernetics became en vogue, the general intellectual climate became yet more favourable for Kantorovich's ideas. Generally, the democratic tendencies of the Thaw and the widespread optimism about scientific progress, reinforced by the Sputnik euphoria, became two decisive factors in fostering the popularity of his notion of optimal planning. Even if the cyberneticists' notion of the interdependence of social systems was different from that which emerged from linear programming, Kantorovich's work in approximation theory and in optimal planning corresponded with the interests of the new synthetic approach of 'economic cybernetics'.

In 1957, in Novosibirsk, the so-called 'Academic Town' was founded to become the science hive of the communist world. Sobolev took charge of the mathematics institute that was one of this ambitious project's priorities. ${ }^{46}$ To attract prominent figures to move east, they were promised nominations as members of the Academy of Sciences, a key position in Soviet academic bureaucracy. This is how, despite his Jewish background, Kantorovich secured election as corresponding member of the Academy of Sciences in 1958. The nomination was also facilitated by the fact that he was nominated not in mathematics but, at first, as corresponding member in economics. ${ }^{47}$

While his colleagues in mathematics belittled Kantorovich for this nomination in economics, his official classification as economist made the established political economists uncertain about the field's identity. ${ }^{48}$ The disjunction first became evident when Kantorovich tried to publish a paper reconciling linear programming and the theory of value, written in 1943. The paper's first title was 'On calculating socially necessary labour time in the conditions of the socialist society'. ${ }^{49}$ In 1945 , it was rejected by the authoritative journal in political economy, Under the Banner of Marxism (Pod znamenem marksizma). Twelve years later, Kantorovich submitted the article to Voprosy ekonomiki in 1957 titled 'On calculating social costs of labour'. After four revisions, the proofs ready for publication were destroyed at least two times, despite Kolmogorov's supporting letter to Nesmeyanov. ${ }^{50}$ Kantorovich sent a furious letter to the editor-inchief, Lev Gatovsky, with copies to Nesmeyanov and Kirillin, asking to return his

46 On Akademgorodok see in particular Paul Josephson, New Atlantis Revisited: The Siberian City of Science, Princeton, NJ: Princeton University Press, 1997; Tatarchenko, op. cit. (5).

47 When Sobolev, Lyapunov and Vainshtein nominated Kantorovich in 1962 for full membership in economics, their attempt failed.

48 Vsevolod L. Kantorovich, Semion S. Kutateladze and Yakov I. Fet (eds.), Leonid V. Kantorovich: Chelovek $i$ uchenyii (Leonid V. Kantorovich: Man and Scientist), vol. 2, Novosibirsk: Scientific Publishing Center of RAS, 2004, pp. $95 \mathrm{f}$.

49 Kantorovich, Kutateladze and Fet, op. cit. (48), p. 69.

50 Kantorovich, Kutateladze and Fet, op. cit. (48), pp. 270 f. This support mattered a lot. Kantorovich explicitly mentions Kolmogorov's appraisal in a 1957 letter to Ambartsumian. Kantorovich, Kutateladze and Fet, op. cit. (48), p. 530. On other occasions, Kolmogorov's support was decisive. In 1957, when Kantorovich was not yet a member of the Academy of Sciences, Kolmogorov submitted his paper on linear optimization and the model of production to the prestigious Proceedings of the USSR Academy of Sciences, which symbolically approved Kantorovich's approach to economics. 
article together with the official editorial decision. Nesmeyanov sent a letter to Gatovsky and it took another year to publish the paper in an abridged form.

This paper opened the way for the more literary, and better-known, book exposition of his method published in 1959, The Best Use of Economic Resources. ${ }^{51}$ In this book, Kantorovich remained cautious in his 'economic' claims, even more so because the book was written for economists (most of the mathematics was, as with Alfred Marshall, moved to appendices). In fact, as he noted in retrospect, his anticipation of the objection that mathematical methods were too reminiscent of Western economics

forced [me] ... to avoid the term 'economic' as much as possible and talk about the organization and planning of production; the role and meaning of the pivor factors [Lagrange multipliers or 'shadow prices'] could be given somewhere in the margin of the second appendix and in the language of Aesop. ${ }^{52}$

Kantorovich had learned the rules of the discourse of political economy. He tried to fashion linear programming in Marxist terms, avoid the association of his 'objectively determined valuations' and market prices, and claim compatibility of his work with the labour theory of value. Like prices, his optimal 'valuations' indicate relative scarcities, connect different branches of the economy, and represent the interests of the social whole. ${ }^{53}$ To dissociate these valuation from free markets, Kantorovich took Marx's idea that socially necessary labour time, as a determinant of value, refers to a social norm, which he reinterpreted in terms of optimization. He rephrased quite naturally the notion of optimality as a normative planning concept. For this reason he emphasized that Marx never quantified his notion of 'socially necessary labour', and that in capitalism such a measure is impossible. ${ }^{54}$ Only the Soviet system could be optimized on the national scale. A price reform using his optimization methods is thus necessary to account for socially necessary costs. Thus he presented mathematical methods in an ideologically sound way, complementing, without replacing, literary Marxian discourse.

In the West, as linear programming had become a legitimate part of mainstream economic analysis, the reaction to his book was immense. He received reviews by established economists such as Tjalling Koopmans, Gerhart Tintner, Maurice Dobb and others. $^{55}$ In his own country, despite his interpretive efforts, the overall reception

51 Leonid V. Kantorovich, Ekonomicheskii Raschet Nailuchshego Ispolzovania Resursov, Moscow: USSR Academy of Science, 1959 (translated as The Best Use of Economic Resources, Cambridge, MA: Harvard University Press, 1965).

52 Kantorovich, op. cit. (8), p. 256. Koopmans, when developing an equivalent theory in the US, had similar problems when downplaying the meaning of prices as propagated by market socialists. Till Düppe and E. Roy Weintraub, Finding Equilibrium: Arrow, Debreu, McKenzie, and the Problem of Scientific Credit, Princeton, NJ: Princeton University Press, 2014.

53 Regarding planning versus programming see the classic study by Alfred Zauberman, The Mathematical Revolution in Soviet Economics, London: Oxford University Press, 1975.

54 Kantorovich, Kutateladze and Fet, op. cit. (48). See also his later talk 'On the tasks of the Academy of Sciences in solving the current problems in the development of the national Economy', ARAN, F. 1916, Op. 1, File 315.

55 See, for example, Benjamin Ward, 'Kantorovich on economic calculation', Journal of Political Economy (1960) 68(6), pp. 545-556; John M. Montias, 'Review of Economic Calculation of the Best Utilization of Resources', Econometrica (1961) 29(2), pp. 252-254; Tjalling C. Koopmans, 'On the evolution of 
among economists was hostile. Reviews by Boyarsky in Gosplan's Planovoe Khoziaistvo and by Gatovsky and Sakov in Kommunist were negative. ${ }^{56}$ The reason was clear: Kantorovich was encroaching on Soviet political economy's academic identity as the gatekeeper of the planned economy. The 'battle for the soul' of Soviet economic knowledge began.

The science war reached its peak when, in April 1960, Kantorovich, together with Nemchinov, organized a large all-union conference on mathematics in economics. Preceded by several attempts to block the conference, it became an important symbolic event that publicly displayed the importance of Kantorovich's work. More than six hundred attendees proved the scope of interest. The 'mathematical lobby' was once more instrumental for the event's success: it was attended by Kolmogorov, Sobolev, Markov Jr, Alexey Lyapunov, Kitov and Glushkov - the last four being the main activists of economic cybernetics. Kantorovich, at the centre of attention, spoke over seven times. Kolmogorov, in his speech, offered an extensive defense by arguing that the mathematical approach to efficiency is superior to existing practices and that, importantly, mathematics should inform economic theory. He argued,

We should not be afraid that the mathematical apparatus of the Marxist theory of socialist economy will have some features of formal affinity with, e.g., theory of 'marginal utility' in bourgeois political economy. This is explained by the commonality of the mathematical apparatus of solving all variational problems and does not touch whatsoever either the peculiarity of the tasks [we] face, or the purity of the Marxian approach to this matter. ${ }^{57}$

Kantorovich's work of 1939', Management Science (1962) 8(3), pp. 264-265; Koopmans, 'A note about Kantorovich's paper Mathematical Methods of Organizing and Planning Production', Management Science (1960) 6(4), pp. 363-365; Leif Johansen, 'Review of The Best Use of Economic Resources', Economic Journal (1967) 77(305), pp. 123-124; E.M. Fels and Gerhard Tintner, 'Mathematical economics in the Soviet Union', Communist Affairs (1967) 5, pp. 3-8; P. Göran Ennerfelt, 'Review: The Best Use of Economic Resources', Swedish Journal of Economics (1965) 67(2), pp. 167-171; Robert Dorfman, 'Review of The Best Use of Economic Resources', American Economic Review (1966) 56(3), pp. 592-597; Maurice Dobb, 'Review: The Best Use of Economic Resources', Science and Society (1967) 31(2), pp. 186-202; Dobb, 'The revival of Soviet economic discussion', Science and Society (1960) 34(4), pp. 289-311; Robert W. Campbell, 'Review: Ekonomicheskii raschet nailuchshego ispol'zovaniia resursov' (Economic Calculation of the Optimum Use of Resources), American Economic Review (1960) 50(4), pp. 729-731. In the same years, his article of 1939 was translated into English. The negotations between translator and editor and referees have been reconstructed by Johanna Bockman and Michael A. Bernstein, 'Scientific community in a divided world: economists, planning, and research priority during the Cold War', Comparative Studies in Society and History (2008) 50(3), pp. 581-613.

56 Aron Boyarsky, 'O matematicheskikh metodakh i trebovaniyakh marksistskoi ekonomicheskoi nauki' (On mathematical methods and the exigencies of Marxist economic science), Planovoe khoziaistvo (1960), 1, pp. 92-96; Lev Gatovsky and Mikhail Sakov, 'O printsipialnoi osnove ekonomicheskikh issledovanii' (On the principled basis of economic research), Kommunist (1960) 15, pp. 79-90; Adolf Katz, 'O nepravilnoi kontseptsii ekonomicheskikh rasschetov' (On the wrong notion of economic calculation), Voprosy ekonomiki (1960) 5, pp. 107-118.

57 Kolmogorov in Kantorovich, Kutateladze and Fet, op. cit. (48), p. 145. Kolmogorov criticized the formalism of 'bourgeois' mathematical economics as a wrong application of mathematics as early as 1938 , in the first version of his entry 'Mathematics' in the Great Soviet Encyclopedia; see Andrey N. Kolmogorov, 'Matematika', in Bolshaya Sovetskaya Encyclopedia, vol. 38, Moscow: Gos. Institut 'Sovetskaya Encyclopedia', 1938, pp. 359-402, 383 f. 
In his final speech, 'On the state and problems of economic science', Kantorovich confronted the Marxist orthodox scholars. His derogatory remarks challenged the academic culture of interpretive, descriptive and historically and institutionally oriented social science:

The computer cannot digest some of our economists' scholarly products ... Any attempt to give them a logical-mathematical, algorithmic form in order to enter them into a computer failed. It turned out that after removing everything that was said 'in general' ... and after pouring out all the 'water', there was either nothing left, or just one big question mark, the formulation of an unsolved problem. ${ }^{58}$

This was an exceptionally open remark. His student Makarov did not recall that he had been so outspoken at any later point. But it was sufficiently polemical to bind his followers together into a new scholarly identity.

Things moved swiftly after this conference. Immediately after the meeting, in May 1960, and following its concluding recommendations, the new committee on applying mathematical methods in economics was created at the Academy of Sciences, headed by Nemchinov. The new research direction was in the process of institutionalization. ${ }^{59}$

Kantorovich's enemies, however, received an additional boost from the West in 1961. The economist Robert Campbell wrote a review with the outrageous title 'Marx, Kantorovich, and Novozhilov: stoimost' [value] versus reality', in which he argued that Kantorovich's ideas meant that Soviet economists would inevitably have 'to free themselves from the limitations of Marxist theory'. ${ }^{60}$ This was the first time that the tensions between Kantorovich's work and Marx's teachings were publicly revealed. Before Campbell, the notion of Kantorovich's economic methods being 'bourgeois' was largely based on thin arguments regarding the fact that - like the bourgeois economic tradition he used mathematics. Most readers would know no more than that. Consequently, reactions to Campbell's article were strong. Without ever challenging foundational ideas of Marxism, and never associating his 'valuations' with neoclassical economics, scholars in the West, as well as his own students, did not know if this attitude was strategic or not. As Katsenelinboigen witnessed, 'Kantorovich became identified with a labor theory interpretation of prices. It has become very hard for me to tell when he does this for tactical reasons and when he honestly subscribes to this position.' ${ }^{61}$ And the Harvard economist Robert Dorfman in 1966:

I should be candid without confessing that at times I found it hard to believe that Kantorovich so seriously misconstrued the implications of the powerful technique that he has done so much to advance. It appeared to me that he was asserting the Marxist orthodoxy of

58 Kantorovich, Kutateladze and Fet, op. cit. (48), p. 98.

59 See A.A. Belykh, 'The perception of L.V. Kantorovich's economic work in the West', (Russian) Ekonom. i Mat. Metody (1990) 6(2), pp. 238-247.

60 Robert W. Campbell, 'Marx, Kantorovich, and Novozhilov: Stoimost' versus reality', Slavic Review (1961) 20(3), pp. 402-418, 403.

61 Katsenelinboigen, op. cit. (33), p. 141. Cursory evidence for Kantorovich's unwillingness to discuss his method in terms of market prices is that his assistant, Makarov, only understood the link between shadow and market prices after Koopmans visited Novosibirsk in 1965. He had never discussed this with Kantorovich before (personal communication). 


\section{2}

Ivan Boldyrev and Till Düppe

the linear programming in the hope of reducing some of the resistances to his recommendations. ${ }^{62}$

By the 1960s, as promised to the Academy of Sciences election committee, Kantorovich had moved to Novosibirsk to become the head of the Laboratory on the Application of Mathematics in Economics in the mathematics department headed by his friend Sobolev. Kantorovich assembled a team of young mathematicians, most of whom were his associates and students from Leningrad, such as Gennady Rubinshtein, Vladimir Bulavski (also credited as Bulavskii), Alexander Rubinov and Gleb Akilov. New students also joined the team, such as Abel Aganbegyan and Valery Makarov, who would all become close collaborators in the years to come and push a new form of economic scholarship in the Academy of Sciences.

Moving to Novosibirsk, Kantorovich also moved away from functional analysis. The last papers on mathematics unrelated to economics were published at the end of the 1950s. Instead, his group actively collaborated with the computing centre of Gury Marchuk, constructing algorithms for developing new computing technologies (the relationship with the cybernetics department that was run by the field leader, Lyapunov, instead, was less intense). As for economic topics, the group worked on the technical analysis of investment efficiency. ${ }^{63}$ This was a contentious issue given that investment efficiency is nothing but rational long-run planning, and required some notion of 'productivity of capital' - which is a taboo in Marxist terms. In a similar vein, optimal-growth theory was another important topic in Novosibirsk of the 1960s, which came with a similar risk. In both corners of the world, von Neumann's model of expanding economy was the point of reference. ${ }^{64}$ A natural path led Kantorovich's students from linear programming to the von Neumann model and to other topics in general equilibrium analysis. In 1965, David Gale and Koopmans, who fostered von Neumann's growth model in the West, visited Novosibirsk separately. However, though the topic of optimal growth was politically wanted, optimal-growth theory in the Soviet Union did not pass the walls of the Academy of Sciences. In other words, perfect and real planning did not intersect. ${ }^{65}$

62 Dorfman, op. cit. (55). Another example of political conservatism is that Kantorovich never referred to the much-discussed convergence theories of the socialist and Western economies; see Zweynert, op. cit. (44).

63 See, for example, Leonid V. Kantorovich, 'Ob ischislenii proizvodstvennykh zatrat', Vopr. Ekonomiki (1960) 1(C), pp. 122-134.

64 See, for example, Leonid V. Kantorovich and Valery L. Makarov, 'Optimal models of long-range planning', in Nemchinov et al. (eds.), Application of Mathematics in Economic Research, Moscow: Mysl., 1965, pp. 7-87; Valery L. Makarov, 'The condition of equilibrium in the von Neumann model' (in Russian), Siberian Mathematical Journal (1962) 3, pp. 476-478; and Makarov, 'The state of equilibrium of a closed linear model of an expanding economy', Economics and Mathematical Methods (1965) 5, pp. 736738.

65 Kantorovich was well read in the growing Western literature on mathematical economics, but was never seriously interested in general equilibrium theory or game theory. Arrow and Debreu's existence proof, for example, might have been interesting from a mathematical point of view, but he thought it relevant only in a market economy. While programming and equilibrium theory were closely related in the context of the Cowles Commission, they were conceived as separate in the Soviet context. See Till Düppe and E. Roy Weintraub, 'Siting the new economic science: the Cowles Commission's activity analysis conference of June 1949', Science in Context (2014), pp. 453-483. 
As for actual economic applications, the discovery of oil resources created demand for transport solutions, such as pipelines and railway networks. In the steel industry, Gossnab commissioned the creation of an automated management system, which is listed as one of Kantorovich's successes, although it is unclear if the programming model was used satisfactorily, or if it mattered much for increasing productivity. ${ }^{66}$ After all, it was not the success in terms of productivity of the Soviet economy that determined the spread of Kantorovich's technocratic ethos in economic debates. Instead, his status was negotiated symbolically through the granting of scientific credit.

\section{Negotiating scientific credit in and beyond the Soviet Union (1965-1975)}

While ideas and methods in the history of science often develop in parallel without any underlying conflict between their epistemic values ever being acknowledged, it is at the occasion of granting personal scientific credit that this confrontation becomes apparent. ${ }^{67}$ The Marxist orthodoxy protested fiercely against granting Kantorovich the highest honour in Soviet science, the Lenin Prize.

The first nomination had occurred already in 1960, a nomination that was submitted by Novozhilov and a group of Leningrad mathematicians. But it was rejected. ${ }^{68}$ In 1963 , Kantorovich was nominated together with Nemchinov and Novozhilov, and again the nomination was rejected. At another attempt, Nemchinov was nominated separately 'in order to avoid desecrating the communist toga of [Nemchinov] with your nonpartisan company', as Vainshtein explained in a letter to Kantorovich in December 1963.69 In 1964, Aganbegyan, Vainshtein and Oleinik published an appraisal of Kantorovich's work in Izvestia, one of the two most-read Soviet newspapers, with equal mention of Nemchinov's and Novozhilov's work. This appraisal was countered by a harsh critique sent to Izvestia by political economists Kronrod and Boyarsky, who was then head of the Research Institute of the Central Statistical Service of the USSR. They argued,

As soon as, contrary to the Marxian labour theory of value, one posits something as a substance of value instead of or parallel to labour - be it land, productive facilities or general capacities, costs of a material or other so-called 'factors of production' - one immediately gets a theory that stands in glaring contradiction with economic reality. ${ }^{70}$

66 On the difficulty of the problem see Michael Ellman, Planning Problems in the USSR: The Contribution of Mathematical Economics to Their Solution, 1960-1971, Cambridge: Cambridge University Press, 1973.

67 As argued at book length in Düppe and Weintraub, op. cit. (52).

68 Kantorovich, Kutateladze and Fet, op. cit. (48), pp. 325-327. The published date of this nomination, 1962, is wrong, according to Kantorovich's son Vsevolod Kantorovich, who holds access to remaining archival material of his father. The help of Anton Dmitriev in providing us with this comment is gratefully acknowledged.

69 Cited in Kantorovich, Kutateladze and Fet, op. cit. (48), p. 571.

70 Kantorovich, Kutateladze and Fet, op. cit. (48), p. 332. About Kronrod as an example of a political economist who was less conformist than were technical economists see Yakov Feygin, 'The honest Marxist: Yakov Kronrod and the politics of Cold War economics in the post-Stalin USSR', in Düppe and Boldyrev, op. cit. (1), pp. 100-126. 


\section{4}

Ivan Boldyrev and Till Düppe

A copy of these articles was sent to the Lenin Prize Committee. In response, Kolmogorov sent an extended reply to the committee accompanied by other letters supporting Kantorovich. The vice president of the Academy of Sciences, Ostrovityanov, jointly with Strumilin, instead mobilized fourteen known economists to send a critical letter against Kantorovich's Lenin Prize to Pravda, the main Soviet newspaper. In return, Sobolev and Lyapunov wrote a countercritique. Neither letter was published and the controversy remained suppressed. ${ }^{71}$ As a result, the award was postponed for a year.

In 1965, Novozhilov, Nemchinov and Kantorovich ultimately jointly received the Lenin Prize. The prize was a symbol of clear success in the ideological struggle over legitimate forms of economic knowledge in Soviet socialism. The prize put the dormant confrontation between political economists and mathematicians on hold, as the division of expertise was officially drawn. However, simultaneously, official recognition increased the burden of public responsibility and reinforced the need for Kantorovich to conform. When Koopmans visited Kantorovich in the summer of 1965, he had the impression of a rather reticent scholar, as he later recalled. 'His contributions are somewhat concealed by self-imposed political cautiousness in the style of writing, sometimes I think beyond the call of duty and necessity' (Koopmans to Kaysen, 8 February 1977). Also, unlike his close friends, Kantorovich did not sign one of the major political campaigns in Soviet mathematics, the 'Letter of 99 Mathematicians' supporting the dissident Aleksandr Esenin-Volpin in 1968.

The younger generation that was inspired by his work, however, profited fully from the optimism now associated in public with mathematical methods in economics. The clearest manifestation was the foundation of the Central Economic Mathematical Institute (CEMI) of the Academy of Sciences, which hosted an entire army of younger talented mathematicians and programmers. The relationship between Kantorovich's institute and CEMI, however, has not been as close as one would expect. Kantorovich, according to Romanovsky, considered the expectations of CEMI to be exaggerated, specifically those relating to the so-called system of optimal functioning of the economy (SOFE) that had the ambition to indeed 'programme the USSR'. ${ }^{72}$

In 1971, Kantorovich returned to Moscow and became head of the research laboratory in the Institute for the Management of the National Economy attached to the State Committee for Science and Technology (GKNT) headed by Vladimir Kirillin. This could be the result of his own wish to reconnect to state institutions and to economic policy, or his wife's desire no longer to be isolated in Novosibirsk. ${ }^{73}$ At this point, the battles over mathematical methods in economics had been won and Kantorovich turned to the business of theoretically modelling small problems, applying programming tools on a local scale, thanks to GKNT's important role in the scientific management of the economy. Kantorovich helped create new laboratories in various regions; becoming more moderate in his ambitions, he left the 'whole economy' to others, and focused on

71 See the comment in Kantorovich, Kutateladze and Fet, op. cit. (48), pp. $330 \mathrm{f}$.

72 For the partial successes but overall failed attempt to take over national planning by this system of optimization models for the whole Soviet economy see Ericson, op. cit. (45).

73 Romanovsky, personal conversation. 
the problems of transport and innovations. ${ }^{74}$ Close to the centre of power, Kantorovich increasingly avoided confrontation with political economists. He rather sought cooperation to see some of his ideas realized in specific sectors. Untypically for an academician, he maintained good relationships with the head of Gosplan, Nikolai Baibakov, and the head of Gossnab, Veniamin Dymshitz. ${ }^{75}$

Meanwhile, Kantorovich's international recognition in operations research and mathematical economics was firmly established. In 1975, Kantorovich, jointly with Koopmans, was selected as the recipient of the Nobel Memorial Prize in Economic Sciences 'for their contributions to the theory of optimum allocation of resources'. It is unclear who nominated him but it was clearly in the interests of the Swedish Academy of Sciences to promote science as a mediator in the Cold War. Koopmans, who promoted a similar agenda, and whose nomination was not a surprise (he was a director of the Cowles Foundation, which was a very influential economics player in the US and the West in general), had always stressed the priority of Kantorovich, which may be why a double nomination was made. ${ }^{76}$ Archival evidence suggests that the prize committee had previously considered Kantorovich. Erik Lundberg, earlier a member, and in 1975 chairman of the committee, had commissioned an overview of Kantorovich's economic approach to linear programming as far back as May 1971. ${ }^{77}$ Whoever nominated Kantorovich, it is very unlikely that any scholar from the Soviet Union was involved. Indeed, from a Soviet perspective, it was not clear at all if the prize should be considered an honour.

The economics prize in memory of Alfred Nobel, the first given to a scholar living in the Soviet Union, put the question of symmetry and asymmetry of economic knowledge across the Iron Curtain on the table. Would it be an insult to the Party to accept it? Should he refuse? At stake were two major issues, an international priority fight and a national power struggle. First, Koopmans insisted that the prize should be equally given to Dantzig, who had first discovered the central algorithm for solving linear

74 Plisko, personal conversation. See also Peters, op. cit. (3).

75 Makarov, personal conversation. Kantorovich might have hoped for connecting yet more to Gosplan via, for example, Dzhermen Gvishiani, married to the daughter of the Soviet prime minister Alexei Kosygin. In 1976, Gvishiani became the head of the new institute, VNIISI (All-Union Scientific Institute of Systems Research), and invited Kantorovich to move there with his GKNT lab. On Gvishiani and Kosygin see Egle Rindzevičiute, The Power of Systems: How Policy Sciences Opened Up the Cold War World, Ithaca, NY and London: Cornell University Press, 2016.

76 Next to the letters from other Nobelists at Cowles, one nomination letter might have been written by the future Nobel Prize-winner Richard Stone. Stone was in touch with Kantorovich from the mid-1960s, and granted him a honorary doctorate in Cambridge in 1976. This relationship is documented in Stone's archive. Papers of J.R.N. Stone, Folder 'Kantorovich', JRNS/3/1/74, Archive Centre, King's College, Cambridge.

77 Leif Johansen (1930-1982) was a Norwegian mathematical economist who wrote an early overview of Kantorovich's economic work. Leif Johansen, 'Soviet mathematical economics', Economic Journal (1966) 76, pp. 593-601. The notes from Johansen's archive were communicated to us by Olav Bjerkholt. Another episode concerns the USSR visit of Herman Wold, a statistician and a member of the prize committee, in September 1973. According to Vsevolod Kantorovich, Wold wanted to be sure that Kantorovich would accept the award jointly with the émigré economist Wassily Leontief, which Kantorovich had to decline for political reasons. There is no independent archival evidence apart from the letters confirming that Wold indeed visited the Soviet Union. Kantorovich, Kutateladze and Fet, op. cit. (16), pp. $510 \mathrm{ff}$. 
optimization problems. Koopmans went as far as to ask Kantorovich to donate a part of his money, such that a third of the total would go to Dantzig. Anonymously, he donated US $\$ 40,000$ to the International Institute for Applied Systems Analysis (IIASA) in Laxenburg, with which Dantzig was associated, and which stood for the institutional integration of economic research in the East and West. Kantorovich did not do so, although he, too, was associated with IIASA. Establishing priority in a definitive way was difficult, on both ideological and conceptual grounds, involving the crucial question of what level of generality matters. Kantorovich, in 1938, did not develop the algorithm in the same general form as Dantzig did, and their formulations differ: Dantzig refers to prices and profits and Kantorovich to output, production capacities and a given plan. ${ }^{78}$ As Dorfman put it, 'Kantorovich-type problems are a proper subset of Dantzig-type on one interpretation; the reverse inclusion holds on another, equally legitimate, interpretation. ${ }^{79}$

A second problem was political. In the same year, the Nobel committee gave Andrei Sakharov, nuclear physicist and disarmament proponent, the Nobel Peace Prize. The Soviet press would thus treat the prize as a form of imperialist political propaganda, and indeed a long list of Soviet academics signed a petition against Sakharov's prize. Clearly, Kantorovich did not wish to make any political affair out of his Nobel Prize, which was not reported by the Soviet press for some time. Romanovsky recalls a long discussion with Kantorovich on the best response - refusing the prize could have been a strong statement in favour of the official political position against Sakharov. Eventually, Kantorovich decided to keep a low profile: not to sign the petition but to accept the prize.

The two acceptance speeches by Kantorovich and Koopmans must have made the audience wonder if they shared the same discursive world. Koopmans emphasized that the same method of allocating resources applied to both systems - he spoke of 'a pre-institutional theory of allocation of resources' ${ }^{80}$ Kantorovich, on the contrary, emphasized that the problems of a socialist economy are different from those of a capitalist economy: 'Before discussing methods and results I think it will be useful to talk about the specific peculiarities of our problems. These are distinctive for the Soviet economy and many appeared already in the years after the October Revolution. ${ }^{\prime 81}$ The nature of economic theory in socialism, according to Kantorovich, is bound to the problem of control of an entire economy, rather than oriented towards specific

78 On priority see furthermore Richard Dorfman, 'The discovery of linear programming', Annals of the History of Computing (1984) 6(3), pp. 283-295. Dorfman claims that linear programming belongs to economics and gives roughly equal credit to Kantorovich, Koopmans and Dantzig. See also Schwartz, who redresses linear programming as a mathematical discipline and establishes Dantzig as the sole legitimate inventor. Benjamin L. Schwartz, 'The invention of linear programming', Annals of the History of Computing (1989) 11(2), pp. 145-147. On von Neumann's influence on Dantzig's work see Düppe and Weintraub, op. cit. (65).

79 Dorfman, op. cit. (78).

80 Tjalling C. Koopmans, 'Concepts of optimality and their uses', in A. Lindbeck (ed.), Nobel Lectures in Economic Sciences (1969-1980), Singapore: World Scientific, 1992, pp. 239-256, 242, original emphasis.

81 Leonid V. Kantorovich, 'Mathematics in economics: achievements, difficulties, perspectives', in Lindbeck, op. cit. (80), pp. 223-231, 223. 
local policy measures. Prices are necessary as the basis for economic calculation and can be determined scientifically: 'The problem is to construct a system of information, accounting, economic indices and stimuli which permit local decision-making organs to evaluate the advantage of their decisions from the point of view of the whole economy. ${ }^{82}$ Kantorovich went on to make a series of positive remarks about Marx and Lenin, and closed with an acknowledgement of the Soviet authorities. According to Romanovsky, the speech was self- rather than state-censored. The need for stressing the difference of the epistemic sphere in the Soviet Union shows how difficult, for Kantorovich, it was to emancipate his research from its institutional embedding. Comparing the two forces of economic knowledge in the Soviet Union - one establishing symmetry of knowledge via the shared goal of prosperity, the other establishing dissymmetry because of Marxian ideology - it seems that the latter weighed more heavily on Kantorovich's career than the former.

As stagnation took hold in the early 1980s, interest in the theory of optimal planning diminished. Many of Kantorovich's initiatives remained piecemeal and experimental. Perceiving that the Soviet Union was losing economic ground, he complained about the lack of optimism regarding plans to create economic plenty to Anatoly Alexandrov, the president of the Academy of Sciences. He wrote, 'The number of industries in which the calculations are made and used [as compared to the 1960s], was reduced by half during the transition from the 10th to the 11th five-year plan.' ${ }^{83}$ But these institutional impediments were not new to Kantorovich's life experience. They would nourish his belief, and that of an entire generation of partisan scholars, that the implementation of mathematical methods would ultimately win out over politics. The partisan technocracy that Kantorovich embodied maintained its belief in the spirit of reform even as its efforts were neutralized by an ever-more rigid bureaucratic state apparatus. 84

Once the blind political forces indeed weakened in the 1980s, planning soon disappeared entirely from the vocabulary of the political class. But Kantorovich, who died in 1986, did not live to see this. His students kept up their stubborn belief in economic reform, and their belief that Kantorovich's presence could have made a difference to how perestroika decayed - though they might have overestimated their teacher's passion for political change.

\section{Conclusion}

In the East and in the West, Cold War science attempted to enhance formal rationality in society and politics. The 'optimization' catchword, here and there, brought together the disciplines of mathematics, economics and management sciences. In the Soviet context, Kantorovich stood for this episode in the history of knowledge. Despite the

82 Kantorovich, op. cit. (81), p. 224.

83 Archive of the Russian Academy of Sciences, ARAN, F. 1916, Op. 1; File 315.

84 To mention but one example, Aleksandr Anchishkin, a graduate from Leningrad '6th course', worked for and collaborated with Gosplan. His macroeconomic forecasting models for technological change rather more influenced the image of Gosplan being scientific than its actual practices. 


\section{8}

Ivan Boldyrev and Till Düppe

institution-free form of optimization methods that ultimately even brought him the Nobel Prize, this rationality was historically situated.

Kantorovich was part of the Soviet intelligentsia that chose, among several possible attitudes, to pursue, as Gordin and Hall called it, a 'reformist technocratic politics from within'. ${ }^{85} \mathrm{He}$ thus became a model of what we have called a partisan technocracy. Kantorovich heavily drew on the established authority that the field of mathematics held in the Academy of Sciences in twentieth-century Russia, and in occidental universities at large. This authority could be incorporated into the institutions of a party dictatorship, and ultimately sufficed to complement the state-founding discourse of Marxist, literary, political economy. Indeed, Kantorovich always framed his method as a method of socialist planning and never faced up to the conflict others saw between these methods and Marx's political economy. Having experienced, unlike his students, Stalin's terror, Kantorovich never challenged the philosophy of political economy up-front but claimed the compatibility of his work with the state's ideologies. Crucially, both Marxist political economy and programming techniques could credibly submit themselves to a nationalist, partisan undertaking. Open for continuous improvements, Kantorovich's technocratic notion of planning was compatible with one major imperative of Soviet ideology: that actual socialism remained an edifice to be built in the future.

Rather than thinking of his work in terms of success or failure, we have tried in this essay to see his career as exemplifying a distinct form of scholarship, and him as a partisan technocrat, characteristic of the Soviet Union. We have shown that in defending and promoting his work, Kantorovich was a perfect Soviet bureaucrat negotiating forces within the Academy of Sciences and the political sphere of the Party. While the resulting institutionalization of mathematical economics has been a success, 'programming the USSR' was never really possible. The same social order that enabled Kantorovich to develop the idea of rational politics in socialism prevented him from making this idea come true.

85 Michael D. Gordin and Karl Hall, 'Introduction: intelligentsia science inside and outside Russia', in Gordin, Hall and Kojevnikov, op. cit. (3), p. 16. 